\title{
DOES THE SURROUNDING VEGETATION INFLUENCE THE FRUIT FLY ASSEMBLAGE IN GUAVA ORCHARDS?
}

\author{
A VEGETAÇÃO DO ENTORNO INFLUENCIA A ASSEMBLÉIA DE MOSCAS-DAS- \\ FRUTAS EM POMARES DE GOIABEIRA?
}

\author{
Kátia da Cruz VARGAS ${ }^{\mathbf{1}}$; Alfredo Raúl ABOT ${ }^{\mathbf{1}}$; Victor Ribeiro ACOSTA ${ }^{2}$; \\ Marcos Henrique Frech TELLES'; José NICÁCIO ${ }^{1}$; Flávio Roberto Mello GARCIA ${ }^{2}$ \\ 1. Universidade Estadual de Mato Grosso do Sul, Aquidauana, MS, Brazil; 2. Universidade Federal de Pelotas, Instituto de Biologia, \\ Departamento de Ecologia, Zoologia e Genética, Pelotas, RS, Brasil. flavio.garcia@ufpel.edu.br
}

\begin{abstract}
This study aimed to evaluate how the surrounding vegetation affects the assemblage of fruit flies. For this, flies were collected in guava orchards with distinct types of surrounding vegetation (exotic pasture, native forest and fruit tree intercropping). The experiment was conducted in Itapora and Dourados, State of Mato Grosso do Sul, Brazil. Weekly samples were collected from March to April 2015. McPhail traps were baited with 5\% hydrolyzed corn protein. Species richness, diversity index and abundance were evaluated for each orchard, as well as the species composition of fruit fly between the environments surrounding the orchard and, finally, the sex ratio. A total of 579 individuals were collected of the species Anastrepha fraterculus, A. montei, A. obliqua, A. sororcula, A. striata, A. turpiniae and A. zenildae. The orchard surrounded by native forest had the highest species richness and Shannon diversity. The species composition differed between environments, with the formation of three distinct groups. The environment surrounding the guava orchard influences the richness, diversity, abundance and sex ratio of fruit flies, indicating that the native forest may provide more resources for the maintenance of these insects.
\end{abstract}

KEYWORDS: Agroecosystems. Anastrepha. Fruit pests. Psidium guajava.

\section{INTRODUCTION}

Brazil is one of the world's leading fruit producers, harvesting 44 million tons/year (ANUÁRIO DE FRUTICULTURA BRASILEIRA, 2018). The country has a significant variety of economically important fruits, including guava (Psidium guajava L.), which places it among the world's largest producers. Guava is among the 15 most produced fruit species in Brazil. In 2017, the area planted was 20.3 thousand hectares with production of 460.515 thousand tons (IBGE, 2017). However, this crop faces some limiting factors regarding its production, with emphasis on the pest complex.

Fruit flies (Diptera: Tephritidae) have economic relevance, mainly the species belonging to the genus Anastrepha (Schiner) and Ceratitis (Wied.). Anastrepha currently holds more than 270 species, with a wide geographical distribution worldwide (NICÁCIO et al., 2011). These insects cause numerous damages in areas of pomiculture, and are considered an important pest of the fruit crops due to the direct damages generated in the fruits and the capacity of adaptation to the environment (AZEVEDO et al., 2010). Those considered as pests cause high losses in several sectors of production and can reach about US\$ 120 million per year, besides being an obstacle to exports of this product (ANUÁRIO DE FRUTICULTURA BRASILEIRA, 2018). In guava, it has been recorded 15 colonizing species of Anastrepha. These species are associated with 200 other hosts (ZUCCHI, 2008).

There are several factors that may determine greater or lesser impact of the fruit fly population on guava crop, such as the environment surrounding the orchard. Areas of native vegetation, because they are not disturbed, can contribute to the biological control of the pest by harboring natural enemies when compared to anthropized environments (MILICZKY; HORTON 2005). Insects can use the vegetation surrounding the orchard as a refuge and may also transit from one environment to another; that is, the insects that predominate in the orchard can move to the surrounding area and vice versa (TAIRA et al., 2013). Thus, they can provide favorable conditions for community maintenance of these insects.

However, it is important to evaluate the conditions of potential insect infestation of fruit flies to choose the location for planting a pomiculture, since in an area with a high population index of these flies there will be a trend towards higher management and control costs (TEIXEIRA et al., 2015). Thus, it is essential to study the influence of the extra-orchard environment on the population of these insects. 
Therefore, the goal of this study was to check the influence of the vegetation surrounding the guava orchards on the fruit fly assemblage.

\section{MATERIAL AND METHODS}

\section{Experimental area}

The experiment was carried out in three orchards with distinct surrounding vegetation located in Itaporã, State of Mato Grosso do Sul (Orchard 1$21^{\circ} 54^{\prime} 22,43 " \mathrm{~S} / 54^{\circ} 41^{\prime} 57,18^{\prime \prime W}$; Altitude - $314 \mathrm{~m}$; Orchard 2- $21^{\circ} 54^{\prime} 22,55^{\prime \prime S} / 54^{\circ} 42^{\prime} 32,04^{\prime \prime W}$; Altitude $-306 \mathrm{~m})$ and Dourados, State of Mato Grosso do Sul

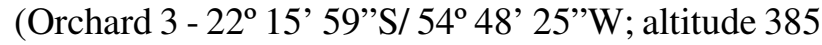
$\mathrm{m})$. The climate according to the Koppen-Geiger classification is Cwa, humid mesothermal with an average annual rainfall of $1500 \mathrm{~mm}$ and average annual temperature of $22^{\circ} \mathrm{C}$ (warm summers and dry winters) (ALVARES et al., 2014). The sampling was systematic randomized.

In Itaporã, State of Mato Grosso do Sul, the experimental area is characterized by two sub-areas of monocrops of guava Novo Milênio, with an area of approximately two hectares each orchard and the distance between orchards of three kilometers. Orchard 1 has its area surrounded by exotic pasture (Urochloa brizantha), with an area of approximately three hectares. Orchard 2 is surrounded by watercourse and native forest, with floristic composition typical of stricto sensu Cerrado having an area of approximately $600 \mathrm{~m}$ wide, with a distance between the forest and the orchard of less than 100 $\mathrm{m}$. Orchard 3 is located in Dourados, State of Mato Grosso do Sul, $47 \mathrm{~km}$ away from Itaporã. This third orchard consists of an agrosystem composed of guava trees intercropped with Mangifera indica (mango), Persea americana (avocado), Citrus limon (lemon) and Bactris gasipaes (peach palm).

\section{Insect sampling}

Flies were sampled weekly from March to April 2015 at the fruiting season of Psidium guajava, with samples of $10 \mathrm{McPhail}$ traps (repetitions) for each experimental subarea except the intercropping with four traps due to the smaller size of the area. The traps were baited with 5\% hydrolyzed corn protein, arranged randomly in the orchard and set at $1.80 \mathrm{~m}$ height in the guava trees.

Subsequently, insects were counted, sexed and stored in $80 \%$ alcohol. Specimens of fruit flies of the genus Anastrepha Schiner were identified using the identification keys of Zucchi (2000a).

\section{Data analysis}

We were submitted to normality testing with the Shapiro-Wilk test and homoscedasticity or homogeneity of the error variance. Subsequently we compare the species richness and diversity of Anastrepha sp. in guava orchards surrounded by native forest, pasture and intercropping environments, a nonparametric Kruskal-Wallis test was applied. The multiple comparison of distribution in the number of flies was performed by the DunnBonferroni bilateral test $(\mathrm{p}<0.01)$. The species richness was also estimated by first-order Jacknife, which makes it possible to estimate richness and sampling efficiency, using the number of species occurring in only one sample (HELTSHE; FORRESTER, 1983). The community was also analyzed for Shannon-Weaver diversity, in which the higher the value of the index the greater the species diversity of the studied community (MAGURRAN, 2013); Modified Hill Evenness, which refers to the distribution of individuals among the species in the environment; and Berger-Parker Dominance, in which the higher the index the greater the likelihood of individuals belonging to the same species, thus, the greater the dominance and the lower the diversity. These analyses were run with the help of software DivEs 4.0 (RODRIGUES, 2017).

The composition of Anastrepha species with the environments were subjected to Multiple Correspondence Analysis (MAROCO, 2007) using the PAST 3.0 software (HAMMER et al., 2013). Finally, sex ratio was obtained by the ratio of the number of females to the total number of captured flies.

\section{RESULTS AND DISCUSSION}

The total number of flies caught in the set of three guava orchards was 579 specimens, with a richness of seven species (Table I). As for richness, the orchard surrounded by native forest had the largest number of species $(S=6)$, with the occurrence of almost all sampled except for Anatrepha montei (Lima, 1934). The lowest richness was obtained in the orchard surrounded by pasture $(S=4)$. The richness observed in the orchard surrounded by pasture was equal to that estimated, and in the environment surrounded by native forest and fruit tree intercropping, it was over $60 \%$ of the estimated value, which allows to affirm that sampling effort and the method were adequate (Table 1).

The diversity index of Anastrepha was significantly influenced by the environment surrounding the orchard, with higher diversity for the environment surrounded by native forest followed by 
pasture and smaller in the intercropping of fruit trees

(Table 1).

Table 1. Fruit flies in three guava (Psidium guajava) orchards surrounded by pasture, native forest and fruit tree intercropping, collected from March to April 2015 in the municipalities of Itaporã and Dourados, State of Mato Grosso do Sul.

\begin{tabular}{|c|c|c|c|c|}
\hline \multirow{2}{*}{ Fruit fly species $(\phi \circ)$} & \multicolumn{3}{|c|}{ Environment surrounding guava orchards } & \multirow[t]{2}{*}{ Total } \\
\hline & Pasture & Native forest & Fruit tree intercropping & \\
\hline Anastrepha fraterculus & 7 & 25 & 19 & 51 \\
\hline Anastrepha montei & 0 & 0 & 1 & 1 \\
\hline Anastrepha obliqua & 3 & 8 & 56 & 67 \\
\hline Anastrepha sororcula & 3 & 46 & 58 & 107 \\
\hline Anastrepha striata & 9 & 70 & 11 & 90 \\
\hline Anastrepha turpiniae & 0 & 1 & 0 & 1 \\
\hline Anastrepha zenildae & 0 & 8 & 0 & 8 \\
\hline Anastrepha spp. $(\widehat{\partial})$ & 8 & 161 & 85 & 254 \\
\hline Total & $30 \mathrm{a}$ & $319 b$ & $230 \mathrm{c}$ & 579 \\
\hline Richness /Jackknife 1 & $4 / 4$ & $6 / 9$ & $5 / 8$ & ------- \\
\hline Shannon-Weaver diversity & $1.27 \mathrm{~b}$ & $1.35 \mathrm{a}$ & $1.23 \mathrm{c}$ & ------ \\
\hline Evenness & 0.92 & 0.75 & 0.76 & ------- \\
\hline Berger-Parker Dominance & 0.41 & 0.44 & 0.40 & ------ \\
\hline Sex ratio & 0.73 & 0.49 & 0.63 & 0.56 \\
\hline
\end{tabular}

Kruskal-Wallis $=\{\mathrm{p}(\mathrm{x}>\mathrm{x} 2) ;(\mathrm{p}<0.001)=(\chi=61.40 ; \mathrm{df}=2 ; \mathrm{n}=233)\}$. The comparison was made by Dunn-Bonferroni bilateral test $(\mathrm{p}$ $<0.001$ ), in which different letters indicate significant differences.

The abundance of flies observed in the collections was significantly different between the environments. The guava orchard with the highest number of flies collected was surrounded by native forest, which represented $55 \%$ of the total, followed by the environment of fruit tree intercropping with $40 \%$ and finally, the orchard surrounded by pasture with $5 \%$ of the total number of individuals (Table 1).

The seven species obtained formed the most prominent set consisting of A. fraterculus (Wiedemann, 1830), A. obliqua (Macquart, 1835), A. sororcula (Zucchi, 1979) and A. striata (Schiner, 1868), which totaled $96.92 \%$ of the total number of females caught. Of the species collected, the set of $A$. sororcula and A. striata corresponds to $60.61 \%$. The species with the highest number of individuals caught was $A$. sororcula. In addition, A. turpiniae (Stone, 1942) and A. zenildae (Zucchi, 1979) were exclusive to the environment surrounded by native forest and A. montei to the intercropping environment (Table 1).

Hill evenness between the environments had the distribution of the number of individuals between the samples in the guava orchard surrounded by the pasture environment greater than in the other two areas. Based on the dominance index, it was verified that no fruit fly species was prominent in the environments (Table 1).
The multiple correspondence analysis applied to know the species composition with the surrounding environment allowed to obtain two dimensions that explained $64.5 \%$ of the total inertia (Figure 1). Axis 1 corresponded to $45 \%$ and had influence of the environments surrounded by native forest and intercropping of fruit trees. Axis 2 explained $19.5 \%$ influenced by pasture. Thus, it was possible to observe a significant association between the species of fruit flies and the surrounding environments in the evaluated guava orchards, forming three groups.

Group 1 represented only by A. striata influenced by the area surrounded by pasture; Group 2 formed by $A$. obliqua and A. montei, which were specific to guava orchard intercropped with fruit trees; Group 3 consists of $A$. sororcula, A. zenildae and $A$. turpiniae, which had affinity with the environment surrounded by native forest. Anastrepha fraterculus did not form a group with another species, having its association with the centroid.

With respect to A. turpiniae, A. zenildae and $A$. sororcula, associations with the less disturbed areas were obtained, being related to environments that represent natural balance or less affected by human interference. However, A. striata had preference for environment with greater disturbance whose attractiveness was only guava. 
The sex ratio of individuals sampled in all three environments was 1.3: 1 , with a sex ratio of $56 \%$ for females and $44 \%$ for males. The guava orchard surrounded by native forest had a ratio of 1 : 1 and when guava orchard was surrounded by fruit tree intercropping, this value was 1.7: 1. As for impacted environmental conditions as is the case of guava crop surrounded by pasture, the sex ratio was $73 \%$, with a proportion of $2.75: 1$ (Table 1).

The seven species of Anastrepha identified in the present study were also reported by Canesin; Uchôa-Fernandes (2007) in the State of Mato Grosso do Sul. Zucchi et al. (2011) and Garcia; Norrbom (2011) reported that the diversity of Anastrepha found is due to the presence of host plants of the family Myrtaceae, including Psidium guajava that was colonized by a greater number of species of Tephritidae. Nicácio; Uchôa (2011) attributed the diversity possibly to the fruiting, because Psidium spp. can have two periods of fruit production per year. Quilici et al. (2014) reported that guava possess volatile substances in fruits that are the main attraction factor of the insect, for feeding, mating or egg laying. Recent study found that $A$. fraterculus females that mated with males exposed to guava volatiles showed higher fecundity than females mated to non-exposed males (BACHMANN et al., 2019). Therefore, it can be inferred that the species collected in the present work are naturally occurring in guava orchards and their attractiveness is due to the availability of fruits, especially in guava orchards subjected to pruning that produce fruit along the year.

The obtained richness was differentiated according to the composition of the vegetation surrounding the guava orchards. The environmental condition of higher or lower degradation is a possible explanatory factor for the occurrence of different richness for these flies. This seems to be a pattern for most insects, since the diversified form or heterogeneity of the environment suggests a greater opportunity for niche establishment (LOPES et al., 2007). In the present work, it was evident that the lower the effect of the impact, the estimated value of occurring species is higher than observed. Bomfim et al. (2007) verified that natural environment not affected by human interference or that had greater ecological balance sustained a greater richness and smaller abundance of species of fruit flies. In this way, because the evaluated orchards are intended for commercial production, they are subjected to the application of insecticides, which certainly interfered at a certain moment with the abundance and richness, besides the effect of anthropization by the preparation of the area for planting the orchard and its management activities.
In the Brazilian native vegetation, Myrtaceae plants are important in the natural forest composition, with numerous fruit species (GRESSLER et al., 2006). This family has species that are hosts of several species of fruit flies with high association (GARCIA; NORRBOM, 2011; ZUCCHI et al., 2011). The natural vegetation is important for the maintenance of the fruit fly population (QUERINO et al., 2014). These areas may have fruit species in common with planted orchards allowing the movement of insects from one environment to another. Jesus-Barros et al. (2012) verified higher Anastrepha infestation rate in wild plant species. Thus, the highest richness of fruit flies obtained in the guava orchard surrounded by native forest in the present work may have been due to alternative hosts that guaranteed the maintenance of the population of these insects in this orchard.

Shannon diversity between sites was higher in the condition of lower environmental degradation. In turn, in the lowest indices, we observed a progressive change to lower population diversity. Bomfim et al. (2007) obtained similar results, with higher Shannon index in environment under lower disturbance when compared with anthropized environment. The diversity of fruit flies is supported by the presence of native fragments adjacent to agricultural areas (QUERINO et al., 2014). Aluja (1993) states that these insects migrate for foraging, searching for a sexual partner, egg laying sites, refuges and escape from predators. However, Malavasi et al. (1983) argue that in areas without availability of fruit or host plants, the displacement of these insects occurs by searching sites for mating, shelter and feeding. Places with a greater variety of fruit trees have higher diversity of Anastrepha spp. (ALUJA et al., 1996). Therefore, it was evident that the areas with preserved environment and the higher diversity of host plants near the orchards were determinant for the occurrence of the greatest number of species and individuals, providing adequate conditions for rest, refuge, reproduction and oviposition.

The abundance of Anastrepha was higher in the guava orchard surrounded by native forest. The families of fruit trees with the highest number of hosts associated with Anastrepha spp. are Myrtaceae, Anacardiaceae, Melastomataceae, Moraceae, Fabaceae and Sapotaceae (ZUCCHI et al., 2011). The first two have the highest number of host species for these insects. Nevertheless, Aluja; Biker (1993) verified that not all the essential resources for the maintenance of the population are provided by host plants, thus emphasizing the importance of foraging in non-host plants. In addition, the architecture of the 
fruit plant also influences the population of fruit flies due to the microclimate generated by the canopy of the plants, mainly regarding the shading, the greater relative humidity and the lower temperature fluctuation. In this way, it can be inferred that native forest has the greatest abundance due to the more complex composition of this agroecosystem, attributed mainly to the preferred host plants of these insects and the quality of the environment to maintain the community of these flies.

The guava orchard surrounded by pasture had a low number of individuals distributed in a few species, corroborating Teixeira et al. (2015). These authors attributed this low fluctuation to the lack of alternative hosts and to climatic factors. Aluja; Birke (1993) verified that the infestation rate was progressive with the increase in fruit availability. Thus, the low number of specimens collected in the present study in this environment was probably due to the scarcity of alternative hosts to meet the reproductive potential of the species, added to the fact that these commercial orchards are subjected to management practices including pest control.

As for the species reported in guava orchards in the present study, A. fraterculus, A. obliqua, A. striata and $A$. sororcula were predominant. These results corroborate Taira et al. (2013), who conducted studies on cultivated and wild host plants of fruit flies in the Cerrado-Pantanal ecotone of the State of Mato Grosso do Sul. Among these, guava was the one attacked by the highest number of Anastrepha species, being these four species of flies the most prominent. Marsaro Júnior et al. (2013) collected species of Anastrepha in a guava orchard in Boa Vista, State of Roraima, where these species of flies were frequent and dominant with $84.8 \%$ of the total sampled individuals. Zucchi et al. (2011) reported the geographic distribution of 54 species of Anastrepha recorded for the Amazon region, where $A$. fraterculus, A. obliqua, A. sororcula and A. striata were also cited. Thus, it is evident that these four species of fruit flies have resilience to colonize hosts in different biomes.

The greatest number of $A$. sororcula and $A$. striata found in the present study was probably associated with the presence of guava that is the primary host of these species, in addition to the generalist habit of $A$. sororcula and a wide geographic distribution for these species. Aluja et al. (1996) verified that despite the diversity in an orchard, the predominance of one or two species is common. They infer that the multiplication of these flies may be due to the presence of host plants, preferably for oviposition and larval development. The generalist habit has been registered for $A$. sororcula (NICÁCIO; UCHÔA, 2011) and for $A$. striata (SILVA et al., 2011a), as well as the polyphagia for the latter species (SILVA et al., 2011a; JESUS-BARROS et al., 2012).

The predominance of fruit fly species in guava monoculture differs between regions (ARAÚJO et al., 2013). For example, for the State of São Paulo, Lemos et al. (2015) reported that $A$. fraterculus is the most frequent species and Zucchi (2008) mentions its wider distribution in Brazilian territory. For the northern region, A. striata is the most frequent (MARSARO JÚNIOR et al., 2013) and $A$. zenildae for the semi-arid region (ARAÚJO et al., 2013). In the State of Mato Grasso do Sul, this fly is predominant in orchards of $P$. guajava (NICÁCIO; UCHÔA, 2011; TAIRA et al., 2013). Therefore, the predominance of $A$. sororcula was possibly due to its association with guava and the geographical region sampled.

Evenness was higher in the guava orchard surrounded by pasture and was similar between the other two areas (Table 1). Araújo et al. (2013) observed a low evenness value (0.59), indicating that the frequency distribution among the species collected was not uniform. Bomfim et al. (2007) inferred that the low evenness is related to the greater predominance of only one species, representing 92\% of the individuals sampled. Thus, the distribution of the species and their number of individuals in the orchard surrounded by pasture are more equitable because they are better distributed since this environment suffers less entry and exit of individuals of other environments.

There was an association of some species with the environments surrounding the guava orchards (Figure 1). Regarding the pasture environment, it had a higher preference for A. striata. Silva et al. (2011a) observed for this species the record of 25 hosts of 16 botanical families, with preference for Myrtaceae. This species of fruit fly has more preference for the genus Psidium spp. (ZUCCHI, 2000b; ZUCCHI et al, 2011; MARSARO JÚNIOR et al., 2013). Marsaro Júnior et al. (2013) found that A. striata was obtained only in guavas. Silva et al. (2011b) observed that it represented 92\% of the individuals caught and was the only one infesting P. guajava. Trassato et al. (2016) verified that this fly is the most frequent and important in guava fruit farming in Boa Vista, State of Roraima. Therefore, the higher number of $A$. striata and its association with $P$. guajava in this environment can be because it is its primary host. 


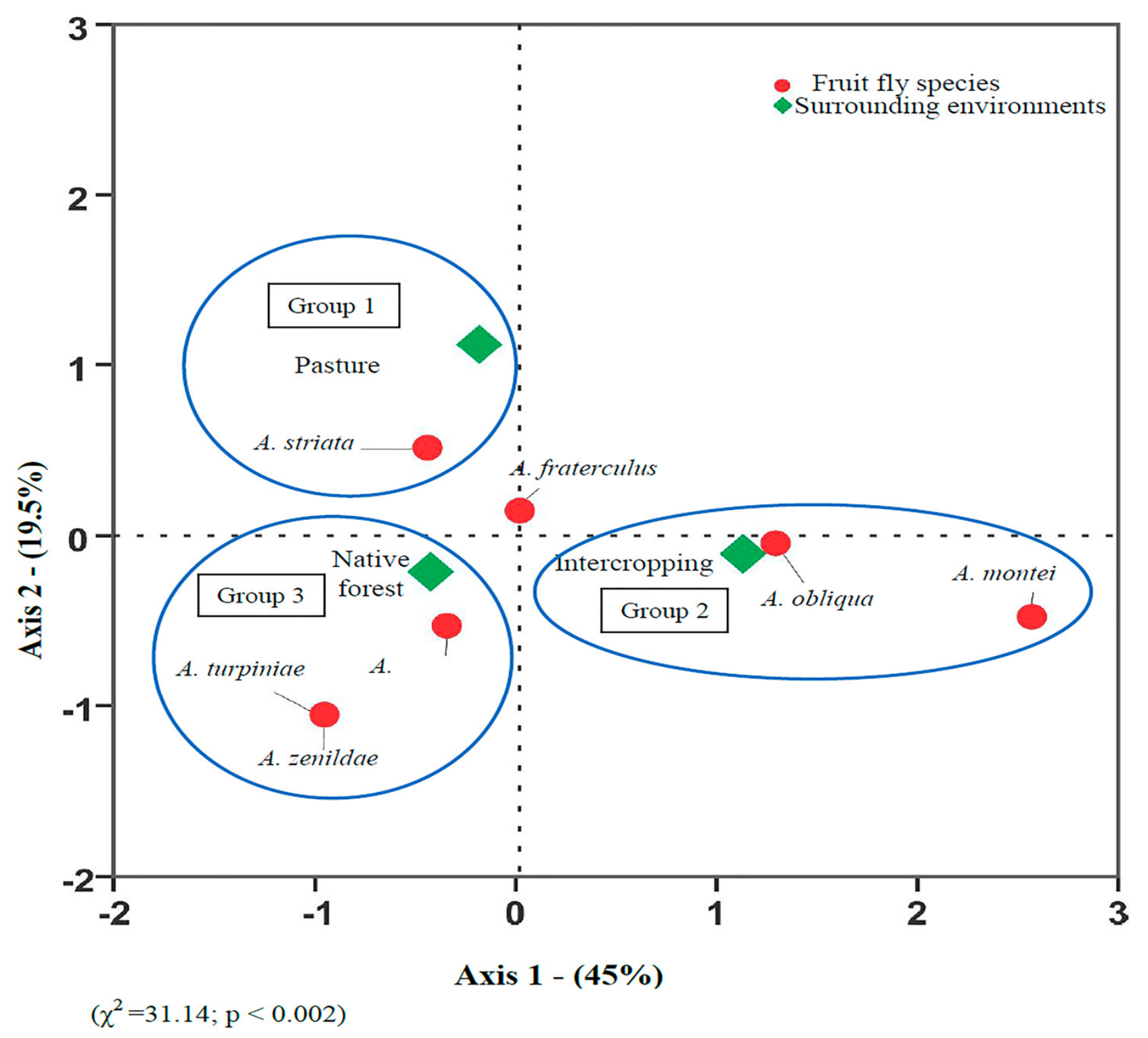

Figure 1. Correspondence analysis biplot between fruit fly species in three guava orchards surrounded by different environments, from March to April 2015, in the municipalities of Itaporã and Dourados, State of Mato Grosso do Sul.

Anastrepha obliqua and A. montei had specificity for the guava orchard surrounded by fruit tree intercropping (mango, avocado, lemon and peach palm) (Group 2) (Figure 1). In this environment, these fruits are primary, secondary, alternative hosts and non-hosts of fruit flies depending on the fly species. Aluja et al. (1996) verified the infestation with $A$. obliqua in $90 \%$ of the material sampled in commercial orchards of Mangifera indica in Mexico. Anastrepha obliqua has a greater preference for host plants of the family Anacardiaceae (BOMFIM et al., 2007; MARSARO
JÚNIOR et al., 2013). In Psidium guajava orchards in different Brazilian states, this species of fly was frequent, dominant or constant (ARAÚJO et al., 2013, MASSARO JÚNIOR et al., 2013). This fly explores the available resources in the orchard, an area with greater number of fruits of its preference allows the maintenance and increase of the population (BOMFIM et al., 2007). Persea americana, Citrus limon and Bactris gasipaes are not considered host plants of Anastrepha sp. (RODRIGUES et al., 2006; JESUS-BARROS et al. 2012). Thus, the association of A. obliqua with the 
orchard surrounded by an intercropping of fruit trees was possibly due to the presence of $P$. guajava and $M$. indica and the management system, since the formation of this agroecosystem probably influenced the stability of communities of fruit flies.

Anastrepha montei is associated with cultivation of Manihot esculenta (GARCIA et al., 2003a; MONTES et al. 2011; GARCIA; NORBOM, 2011) and Jatropha sp. (ZUCCHI, 2000b; QUERINO et al., 2014). The infestation of fruit flies in cassava, where about $35 \%$ and $25 \%$ of the individuals respectively caught in cassava were $A$. montei. Therefore, possibly the capture of the only specimen in this environment is due to the presence of cassava or pine nut brave in the vicinity of the orchard because the study is located in a region with predominance of family farming, where cassava is common (STRIKIS et al. (2012).

A. sororcula, A. turpiniae and A. zenildae had preference for the guava orchard surrounded by native forest (Group 3). For the three species of flies, Zucchi et al. (2011) reported a wide geographical distribution in Brazil and association with host plants of Myrtaceae and Anacardiaceae. These species have $P$. guajava as a common host plant. Taira et al. (2013) observed that among the evaluated fruit species, $P$. guajava was the one that had the highest infestation by these species of flies. These three flies were associated with guava orchards or forests (QUERINO et al., 2014). Thereby, the composition of A. sororcula, A. zenildae and A. turpiniae in the environment surrounded by native forest was evident because $P$. guajava was the recognized host of these flies.

Anastrepha fraterculus was not influenced by the characteristics of the surroundings of guava orchards. Melo et al. (2016) caught $66.45 \%$ of $A$. fraterculus in domestic orchards, emphasizing their generalist habit and preference for Myrtaceae. The dominance of this fly was recorded in orchards of $P$. guajava (NICÁCIO et al., 2018; ALVES et al., 2019) and Acca sellowiana (Berg) (ROSA et al., 2018). However, in periods without fruiting, the peak population of $A$. fraterculus is possibly due to the presence of host plants in the vicinity of the orchard (GARCIA et al., 2003b, LEMOS et al., 2015). Therefore, considering the marked polyphagia that characterizes A. fraterculus, it can be inferred that in monoculture with pasture surrounding, the attractiveness was only of this fruit, while in the other two environments, its presence was due to the availability of guava as well as the diversity of native and cultivated hosts.

The difference in sex ratio of the flies among the orchards may have been influenced by the surrounding vegetation. The population fluctuation of males and females can be influenced by the number of insects caught and differentiation of the attractiveness of each sex for the food solution used in the traps (BORTOLI et al, 2016), volatile compounds present in guava (MALO et al., 2005) and the ripening stage of the fruits (CORNELIUS et al., 2000). Aluja; Birke (1993) verified a correlation between the use of food resources and the characteristics of the habitat for sex ratio. Therefore, the variation in the number of females and males observed in the present study was influenced by several factors such as those intrinsic to the insect and by the diversity of host plants with different fruit ripening stages in the surrounding areas. In females, the protein requirement for their sexual maturity lead to being captured in greater numbers in traps baited with hydrolyzed corn protein, causing difference in the sex ratio.

\section{CONCLUSIONS}

The environment surrounding the guava orchard influences the species richness, diversity, abundance and sex ratio of fruit flies.

The native forest stands out for providing alternative food resources, refuge, suitable microclimate and favorable conditions for reproduction, for the maintenance of the community.

When possible, we suggest that the most distant areas of native forests be chosen for the establishment of orchards.

RESUMO: Este estudo teve como objetivo avaliar como a vegetação do entorno dos pomares afeta a assembleia de moscas-das-frutas. Para isto, foram coletadas moscas em pomares de goiabeiras com distintos tipos de vegetação no entorno (pastagens exóticas, mata nativa e fruticultura). O experimento foi conduzido em Itaporã e Dourados, Estado do Mato Grosso do Sul, Brasil. Amostras semanais foram coletadas de março a abril de 2015. As armadilhas McPhail foram iscadas com 5\% de proteína hidrolisada de milho. A riqueza de espécies, o índice de diversidade e a abundância foram avaliados para cada pomar, assim como a composição de espécies de moscas-das-frutas entre os ambientes do entorno do pomar e razão sexual. Um total de 579 indivíduos foram coletados das espécies Anastrepha fraterculus, A. montei, A. obliqua, A. sororcula, A. striata, A. turpiniae e A. zenildae. O pomar cercado por mata nativa apresentou maior riqueza de espécies e diversidade de Shannon. A 
composição das espécies diferiu entre os ambientes, com a formação de três grupos distintos. $\mathrm{O}$ ambiente do entorno do pomar de goiabeira influencia a riqueza, diversidade, abundância e razão sexual das moscas-dasfrutas, indicando que a mata nativa pode fornecer mais recursos para a manutenção desses insetos.

PALAVRAS-CHAVE: Agroecossistemas. Anastrepha. Pragas de frutas. Psidium guajava

\section{REFERENCES}

ANUÁRIO BRASILEIRO DA FRUTICULTURA. Santa Cruz do Sul: Editora Gazeta. p. 92, 2018.

ALVARES, C. A.; STAPE, J. L.; SENTELHAS, J. L. M. G.; SPAROVEK, G. Koppen Climate Classification map for Brasil. Meteorologische Zeitschrife, v. 22, n. 6, p. 711-728, 2014.

ALUJA, M. The study of movement in tephritid flies: review of concepts and recente advances. In: ALUJA, M.; LIEDO, P. Fruit flies: biology and management. New York: Springer-Verlag, p. 105-113, 1993.

ALUJA, M.; BIRKE, A. Habitat use by adults of Anastrepha obliqua (Diptera: Tephritidae) in a Mixed Mago and tropical plum orchard. Annals of the Entomological Society of America, v. 86, n. 6. p. 799-812, 1993.

ALUJA, M.; CELEDONIO-HURTADO, H.; LIEDO, P.; CABRERA, M.;CASTILLO, F.; GUILLÉN, J.; RIOS, E. Seasonal population fuctuations and ecological implications for management of Anastrepha fruit fies (Diptera: Tephritidae) in comercial orchards in Southern Mexico. Journal of Economic Entomology, v. 89, n. 3, p. 654-667, 1996.

ALUJA, M.; DIAZ-FLEISCHER, F.; ARREDONDO, J. Nonhost Status of Commercial Persea americana 'Hass' to Anastrepha ludens, Anastrepha obliqua, Anastrepha serpentina, and Anastrepha striata (Diptera: Tephritidae) in Mexico. Journal of Economic Entomology, v. 97, n. 2. p. 293-309, 2004.

ALVES, J; DE BRITO, C.; OLIVEIRA, R.;, CORSATO, C.; SILVA, J.; BARBOSA, V.; BATISTA, J. Food attractants used in the fruit fly monitoring (Diptera: Tephritidae) in a commercial orchard of Psidium guajava. Journal of Experimental Agriculture International, v. 34, n. 4, p. 1-10, 2019.

ARAÚJO, E. L.; RIBEIRO, J. C.; CHAGAS, M. C. M., VIVIAN SIQUEIRA DUTRA S.; SILVA, J. G. Moscas-das-frutas (Diptera: Tephritidae) em um pomar de goiabeira, no semiárido brasileiro. Revista Brasileira de Fruticultura, v. 35, n. 2, p. 471-476, 2013.

AZEVEDO, F. R.; GUIMARÃES, J. A.; SIMPLÍCIO, A. A. F.; SANTOS, H. R. Análise faunística e flutuação populacional de moscas-das-frutas (Diptera: Tephritidae) em pomares comerciais de goiaba na região do cariri cearense. Arquivos do Instituto Biológico, v. 77, n. 1, p. 33-4, 2010.

? W. H.; PARKER, F. L. Diversity of planktonic Foraminifera in deep-sea sediments. Science, 168, 1345-1347, 1970.

BACHMANN, G. E.; DEVESCOVI, F.; NUSSENBAUM, A. L.; MILLA, F. H.; SHELLY, T. E.; CLADERA, J. L.; FERNÁNDEZ, P. C.; VERA, M. T.; SEGURA, D. F. Mate choice confers direct benefits to females of Anastrepha fraterculus (Diptera: Tephritidae). bioRxiv 584128; 2019 doi: https://doi.org/10.1101/584128

BOMFIM, D. A.; UCHÔA-FERNANDES, M. A.; BRAGANÇA, M. A. L. Biodiversidade de moscas-dasfrutas (Diptera: Tephritidae) em matas e pomares domésticos de dois municípios do Estado do Tocantins, Brasil. Revista Brasileira de Entomologia, v. 51, n. 2, p. 217-223, 2007.

BORTOLI, L; MACHOTA JR., R.; GARCIA, F. R. M.; BOTTON, M. . Evaluation of food lures for ffruit flies (Diptera: Tephritidae) captured in a Citrus Orchard of the Serra Gaúcha. The Florida Entomologist, v. 99, p. 381-384, 2016. 
CANESIN, A.; UCHÔA-FERNANDES, M. A. Análise faunística e flutuação populacional de moscas-dasfrutas (Diptera, Tephritidae) em um fragmento de floresta semidecidua em Dourados, Mato Grosso do Sul, Brasil. Revista Brasileira de Zoologia, v. 24, n. 1, 185-190, 2007.

CORNELIUS, M. L.; DUAN, J. J; MESSING, R. H. Volatile hot fruit odors as attractants for the oriental fruit fly (Diptera:Tephritidae). Journal of Economic Entomology, v. 93, n. 1, p. 92-100, 2000.

GARCIA, F. R. M.; CAMPOS, J. V.; CORSEUIL, E. . Análise faunística de espécies de moscas-das-frutas (Diptera: Tephritidae) na Região Oeste de Santa Catarina. Neotropical Entomology, v. 32, n. 3, p. 421-426, 2003a.

GARCIA, F. R. M.; CAMPOS, J. V.; CORSEUIL, E. . Flutuação populacional de Anastrepha fraterculus (Wiedemann, 1830) (Diptera, Tephritidae) na Região Oeste de Santa Catarina, Brasil. Revista btasileira de Entomologia, v. 47, n. 3, p. 415-420, 2003 b.

GARCIA, F. R. M.; NORRBOM, A. L. Tephritoid flies (Diptera, Tephritoidea) and their plant hosts from the state of Santa Catarina in southern Brazil. The Florida Entomologist, v. 94, p. 151-157, 2011.

GRESSLER, E.; PIZO, M. A.; MORELLATO, P. C. Polinização e dispersão de sementes em Myrtaceae do Brasil. Revista Brasileira Botânica, v. 29, n. 4, p. 509-530, 2006.

HAMMER, O.; HARPER, D. A. T.; RYAN, P. D. PAST version 3.0: Paleontological statistics software package for education and data analysis. palaeontologia electronica, 4:9, 2013.

HELTSHE, J. F.; FORRESTER, N. E. Estimating species richness using the jackknife procedure. Biometrics, v. 39, p. 1-11, 1983.

IBGE- Instituto brasileiro de Geografia e Estatística. 2017. Produção Agrícola Municipal: Culturas temporárias e permanentes. Rio de Janeiro RJ, v. 41, p. 1-100.

JESUS-BARROS, C. ADAIME, R.; OLIVEIRA, M. N.; SILVA, W. R.; COSTA-NETO, S. V.; SOUZAFILHO, M. F. Anastrepha (Diptera: Tephritidae) species their hosts and parasitoids (Hymenoptera: Braconidae) in five Municipalities of the state of Amapá, Brazil. Florida Entomologist, v. 95, n.3, p. 694-705, 2012.

LEMOS, L. J. U.; SOUZA-FILHO, M. F.; URAMOTO, K.; LOPES, G. N.; ZUCCHI, R. A. Espécies de Anastrepha (Diptera: Tephritidae) em pomares de goiaba: diversidade, flutuação populacional e fenologia do hospedeiro. Arquivos do Instituto Biológico, v. 82, p.1-5, 2015.

LOPES, L. A.; BLOCHTEIN, B.; OTT, A. P. Diversidade de insetos antófilos em áreas com reflorestamento de eucalipto, Município de Triunfo, Rio Grande do Sul, Brasil. Iheringia Série Zoologia, v. 97, n. 2, p. 181-193, 2007.

MAGURRAN, A. E. Measuring Biological Diversity. Princeton: Princeton University Press. p.167, 2013.

MALAVASI, A.; MORGANTE, J. S.; PROKOPY, R. J. Distribution and activities of Anastrepha fraterculus (Diptera:Tephritidae) flies on host and nonhost trees. Annals of the Entomological Society of America, v. 76. p. 286-292, 1983.

MALO, E. A.; CRUZ-LÓPEZ, L.; TOLEDO, J.; MAZO, A.; VIRGEN, A.; ROJAS, J. C. Behavioral and electrophysiological responses of the mexican fruit fly (Diptera: Tephritidae) to guava volatiles. Florida Entomologist, v. 88, n. 4. p. 364-371, 2005.

MAROCO, J. Análise estatística com utilização do SPSS. 3.ed. Lisboa: Silabo, 2007. 822p. 
MARSARO JÚNIOR, A. L.; DEUS, E. G.; RONCHI-TELES, B.; ADAIME, R.; SILAVA JÚNIOR, R. J. Species of Anastrepha (Diptera:Tephritidae) captured in a guava orchard (Psidium guajava L., Myrtaceae) in Boa Vista Roraima, Brazil. Brazilian Journal of Biology, v. 73, n. 4, p. 879-886, 2013.

MELO, E. A. S. F.; SANTOS, O. O.; ROCHA, R. B.; PEDRO CARLOS STRIKIS, P. C.; BITTENCOURT, M. A. L. Diversity of frugivorous flies (Tephritidae e Lonchaeidae) in three municipalities in southern Bahia. Arquivos do Instituto Biológico, v. 83. p. 1-7, 2016.

MILICZKY, E. R.; HORTON, D. R. Densities of beneficial arthropods within pear and apple orchards affested by distance from adjacente native habitat and association of natural enemies with extra-orchard host plants.

Biological Control, v. 33, p. 249-259, 2005.

MONTES, S.M. N. M.; RAGA, A .; SOUZA-FILHO, M. F. Levantamento de espécies de Anastrepha (Diptera: Tephritidae) em áreas de cucurbitáceas sob sistema de mitigação de risco. Revista Arquivos do Instituto Biológico, v. 78, n. 2, p. 317-320, 2011.

NICÁCIO, J.; UCHÔA, M. A. Diversity of frugivorous flies (Diptera: Tephritidae and Lonchaeidae) and their relationship with host plants (Angiospermae) in environments of south pantanal region, Brasil. Florida Entomologist, v. 94, n. 3, p. 443-466, 2011.

NICÁCIO, J; OLIVEIRA, I; UCHOA, M. A.; FACCENDA, O; ABOT, A. R.; FERNANDES, M. G.; GARCIA, F. R. M. Sequential sampling plan for fruit fly species of the Genus Anastrepha (Diptera: Tephritidae) in guava orchards. Anais da Academia Brasileira de Ciências, v. 90, n. 4, p. 3607-3614, 2018.

QUERINO, R. B.; MAIA, J. B.; LOPES, G. N.; ALVARENGA, C. D.; ZUCCHI, R. A. Fruit fly (Diptera: Tephritidae) community in guava orchards and adjacente fragments of native vegetation in Brazil. Florida Entomologist, v. 95, n. 2, 2014, p.778-786.

QUILICI; S. ATIAMA-NURBEL, T.; BRÉVAULT, T. Plant Odors as Fruit Fly Attractants. In: SHELLY, T.; EPSKY, N.; JANG, E. B.; REYES-FLORES, J.; VARGAS, R. Trapping and the Detection, Control, and Regulation of Tephritid Fruit Flies: Lures, Area-Wide Programs, and Trade Implications. Springer, p. 119144, 2014.

RODRIGUES, S. R.; NANTES, L. R.; DE SOUZA, S. R.; ABOT, A. R.; UCHÔA-FERNANDES, M. A. Moscas frugívoras (Diptera, Tephritoidea) coletadas em Aquidauana, MS. Revista Brasileira de Entomologia, v. 50, n. 1. p. 131-134, 2006.

RODRIGUES, W. C., 2017. DivEs - Diversidade de Espécies versão 4.0 - WCR. Studio. Disponível em: $<$ http://dives.ebras.bio.br>.

ROSA, J. M.; NUNES, M. Z; BOFF, M. I. C.; GARCIA, F. R. M.; BOFF, P.; FRANCO, C.R .Fruit fly (Diptera: Tephritidae) assemblage in a feijoa orchard in Santa Catarina State, Brazil. Revista Colombiana de Entomologia, v. 44, n. 1, p. 110-115, 2018.

SILVA, R. A., DEUS, E. G., PEREIRA, J. D. B., JESUS, C. R., SOUZA-FILHO, M. F.; ZUCCHI, R. A. Conhecimento sobre moscas-das-frutas no Estado do Amapá. In: SILVA, R. A.; LEMOS, W. P.; ZUCCHI, R. A. Moscas-das-frutas na Amazônia brasileira: diversidade, hospedeiros e inimigos naturais. Embrapa Amapá, Macapá, 2011a, p. 223-236.

SILVA, R. A.; LIMA, A. L.; XAVIER, S. L. O.; SILVA, R. S.; MARINHO, C. F.; ZUCCHI, R. A. Anastrepha species (Diptera: Tephritidae), their hosts and parasitoids in Southern Amapá State, Brazil. Biota Neotropical, v. 11, n. 3, p. 431-436, 2011 b. 
STRIKIS, P. C. MARSARO JÚNIOR, ADAIME, R.; LIMA, C. R. First report of infestation of cassava fruit, Manihot esculenta, by Neosilba perezi (Romero e Ruppell) (Lonchaeidae) in Brazil. Brazilian Journal of Biology, v.72, n. 3, p.631-632, 2012.

TAIRA, T. L.; ABOT, A. R.; NICÁCIO, J.; UCHÔA, M. A. RODRGUES, S. R.; GUIMARÃES, J. A. Fruit (Diptera: Tephritidae) and their parasitoids on cultivated and wild hosts in the Cerrad-Pantanal ecotone in Mato Grosso do Sul, Brazil. Revista Brasileira de Entomologia, v. 57, n. 3, p. 300-308, 2013.

TEIXEIRA, R.; BOFF, M. I. C.; RIBEIRO, L. G.; BOFF, P. Bordadura de pomar e flutuação populacional de Anastrepha fraterculus (Diptera: Tephritidae) em sistema orgânico de produção de maçã. Scientia Agraria, v.16, n.1, p.33-39, 2015.

THOMAS, D. B.; HOLLER, T. C.; HEATH, R. R.; SALINA, E. J.;MOSES, A. L. Trap-lure combinations for surveillance of Anastrepha fruit flies (Diptera:Tephritidae). Florida Entomologist, v. 84, n. 3, p. 344-351, 2001.

TRASSATO, L. B.; LIMA, A. C. S.; BANDEIRA, H. F. S.; MONTEIRO NETO, J. L. L.; SILVA, E. S.; RONCHI-TELES, B. Diversidade e índice de infestação de Anastrepha spp. em goiabeiras comerciais de Boa Vista, Roraima. Revista Brasileira de Ciências Agrárias, v.11, n.4, p.317-322, 2016.

ZUCCHI, R. A. Taxonomia. In: MALAVASI, A.; ZUCCHI, R. A. Moscas-das-frutas de importância econômica no Brasil: conhecimento básico e aplicado. Ribeirão Preto: Holos Editora, p.13-25, 2000a.

ZUCCHI, R. A. Espécies de Anastrepha, Sinonímias, Plantas Hospedeiras e Parasitoides. In: MALAVASI, A. ZUCCHI, R. A. Moscas-das-frutas de importância econômica no Brasil: conhecimento básico e plicado. Ribeirão Preto: Holos Editora, p. 41-48, 2000b.

ZUCCHI, R.A. 2008. Fruit flies in Brazil - Anastrepha species their host plants and parasitoids. Disponível em: <www.lea.esalq.usp.br/anastrepha/, updated on March 14, 2017>. Acessado em: 22 de Abril de 2017.

ZUCCHI, R. A.; SILVA, R. A.; DEUS, E. G. Espécies de Anastrepha e seus hospedeiros na Amazônia brasileira. In: SILVA, R. A.; LEMOS, W. P.; ZUCCHI, R. A. Moscas-das-frutas na Amazônia brasileira: diversidade, hospedeiros e inimigos naturais. Macapá: Embrapa Amapá, p. 51-70, 2011. 